\title{
Multilevel Analysis on the Association of Job Satisfaction and Organization Commitment with Performance of Family Planning Counsellor in Yogyakarta
}

\author{
Ikhtiarisca Olifia Mufidatun'), Didik Gunawan Tamtomo), Bhisma Murti'1) \\ 1)Masters Program in Public Health, Universitas Sebelas Maret \\ 2)Masters Program in Family Medicine, Universitas Sebelas Maret
}

\section{ABSTRACT}

Background: Performance is an important thing in an organization's efforts to achieve the goals. To evaluate employees objectively, a supervisor must be able to measure their performance level. There are many job characteristics that employees consider, but a group of job characteristics tends to be collectively evaluated in the same way. This study aimed to analyze the effect of job satisfaction and organizational commitment on the employee performance of the Family Planning Counselors in Yogyakarta

Subjects and Method: This study used a crosssectional study. This study was conducted in the office of Family Planning Field Officer (PKB), Yogyakarta, Central Java, from January to February, 2020. There were 200 employees as the sample of this study. The sample was collected using simple random sampling. The dependent variable was the performance of PKB employees. The independent variables were job satisfaction and organizational commitment. The data were collected using questionnaires. The data were analyzed using multilevel analysis with Stata 13. Results: The performance of PKB employess increased with poor good job satisfaction $(b=2.36$; $95 \% \mathrm{CI}=1.49$ to $3.22 ; \mathrm{p}<0.001)$ and good organizational commitment $(\mathrm{b}=1.68 ; 95 \% \mathrm{CI}=0.89$ to 2.47; $\mathrm{p}<0.001)$. PKB office had a contextual effect on employee performance with ICC $=10.75 \%$.

Conclusion: Job performance is affected by job satisfaction and organizational commitment. PKB Office has a strong contextual effect on job performance.

Keywords: employee performance, job satisfaction, organizational commitment

\section{Correspondence:}

Ikhtiarisca Olifia Mufidatun. Masters Program in Public Health, Universitas Sebelas Maret. Jl. Ir. Sutami 36A, 57126, Surakarta, Central Java. Email: riscaolifia@gmail.com. Mobile: +6282220030006

Cite this as:

Mufidatun IO, Tamtomo DG, Murti B (2020). Multilevel Analysis on the Association of Job Satisfaction and Organization Commitment with Performance of Family Planning Counselors in Yogyakarta. J Health Policy Manage. 05(03): 197-203. https://doi.org/10.26911/thejhpm.2020.05.03.05.

(C) (F) Journal of Health Policy and Management is licensed under a Creative Commons Journal of Health Policy and Management is licensed under a Creati

\section{BACKGROUND}

Performance is an important thing in an organization's efforts to achieve its goals so that various activities must be carried out by the organization to improve it. One of the ways to do this is through performance appraisal. Bangun (2012) stated that performance appraisal was a formal assessment of how good employees are doing their job. To be able to evaluate employees objectively, a supervisor must be able to measure their performance level. Performance measurement can be used as a standard measure used by employees in directing their efforts through a certain set of priorities.

Siagian (2003) stated that job satisfaction was a person's perspective, both positive and negative about their job. Job satisfaction is a generalization of attitudes towards a job based on various aspects of the job. There are 
many job characteristics that employees consider, but a group of job characteristics tends to collectively be evaluated in the same way.

Organizational commitment is defined as the relative strength of the identification of individuals with involvement in a particular organization. If the concept of organizational commitment is used as a predictor of employee retention, it becomes the focus of managers in general departments and human resources in many organizations. The main responsibility of a human resource (HR) manager is to understand the factors that make an employee commit and use that knowledge to increase employee retention and productivity. Organizational commitment describes the status of employees' commitment to the organization and the identification of employees with organizational values and goals (Osiokalu et al., 2015).

\section{SUBJECTS AND METHOD}

\section{Study Design}

This study used an analytical observational method with a cross-sectional approach. This study was carried out in the office of Family Planning Field Officer (PKB) in D.I.Yogyakarta from January to February 2020.

\section{Population and Sample}

The population of this study was $200 \mathrm{PKB}$ employees at D.I.Yogyakarta as the subjects of the study. This study used simple random sampling.

\section{Study Variables}

The dependent variable was employee performance. The independent variables were job satisfaction and organizational commitment.

\section{Operational Definition of Variables} Employee performance was the achievement result of efforts that have been made. It could be measured by certain indicators such as stress, work environment, workload, and salary. The measuring instrument was questionnaires.
The data scale was categorical data. The data was converted into dichotomous data to facilitate the analysis.

Job satisfaction was measured by a series of happy feelings and emotions of employees, related to several aspects of their work, such as co-workers, income received, leader, job, and promotional opportunities provided by the company. The measuring instrument was questionnaires. The data scale was continuous data. The data was converted into dichotomous data to facilitate the analysis.

Organizational commitment was an attitude that reflected employee loyalty to the organization. It was a continuous process in which organizational members expressed their concern for the organization, organizational success, and continuous progress. The measuring instrument was questionnaires. The data scale was continuous data. The data was converted into dichotomous data to facilitate the analysis.

\section{Data Analysis}

Univariate analysis was used to describe each dependent and independent variable. The data were classified based on the type of data. The data were put into a frequency distribution table. Bivariate analysis was used to determine the relationship between job satisfaction and organizational commitment and employee performance as measured by the Chi-square test. The multilevel analysis explained the effect of job satisfaction and organizational commitment on employee performance at the office level of Family Planning Field Officer (PKB). The univariate, bivariate, and multilevel analysis used the Stata 13 program.

\section{Research Ethic}

Research ethics included informed consent, anonymity, confidentiality, and ethical clearance. The ethical clearance in this study came from the Health Research Ethics Committee of Dr. Moewardi Hospital, Surakarta, No. 1465/XI/HREC/2019. 


\section{RESULTS}

\section{Sample Characteristics}

Based on table 1, 196 respondents (98.00\%) aged <35 years old. 193 respondents (96.$50 \%)$ were married. Most of the sexes were male or 101 people (50.50\%).

\section{Univariate analysis}

Based on table 2, the measurement of the job satisfaction variable showed the mean and SD values by $36 \pm 7.41$ with the lowest value by 21 and the highest value by 72 . The organizational commitment variable showed the mean and SD values by $24 \pm 6.55$ with the lowest value by 18 and the highest value by 48 .
The employee performance variable showed the mean and SD values by $40 \pm 8.67$ with the lowest value by 32 and the highest value by 80 .

Table 3 presents the dichotomous data of the univariate analysis from 200 employees. 129 people $(64.50 \%)$ had good job satisfaction and 71 people $(35.50 \%)$ had poor job satisfaction. 91 people (45.50\%) had a good orgaknizational commitment and 109 people (54.50\%) had a poor organizational commitment. 114 employees (57.00\%) had a good performance and 86 employees (43.00\%) had a poor performance.

Table 1. The characteristics of the study subjects

\begin{tabular}{llcc}
\hline \multicolumn{1}{c}{ Variable } & \multicolumn{1}{c}{ Criteria } & Frequency (n) & Percentage (\%) \\
\hline Age & $<35$ years & 196 & 98.00 \\
& $\geq 35$ years & 4 & 2.00 \\
Marital status & Single & 7 & 3.50 \\
& Married & 193 & 96.50 \\
Sex & Male & 101 & 50.50 \\
& Female & 99 & 49.50 \\
\hline
\end{tabular}

Table 2. Univariate Analysis (continuous data)

\begin{tabular}{lccccc}
\hline \multicolumn{1}{c}{ Variable } & N & Mean & SD & Min. & Max. \\
\hline Job satisfaction & 200 & 36.40 & 7.41 & 21 & 72 \\
Organizational commitment & 200 & 24.02 & 6.55 & 18 & 48 \\
Employee performance & 200 & 40.02 & 8.67 & 32 & 80 \\
\hline
\end{tabular}

Tabel 3. Univariate Analysis (data dikotomi)

\begin{tabular}{llcc}
\hline \multicolumn{1}{c}{ Variable } & Criteria & Frequency (n) & Percentage (\%) \\
\hline Job satisfaction & Low & 71 & $35 \cdot 50$ \\
& High & 129 & 64.50 \\
Organizational & Weak & 109 & 54.50 \\
commitment & Strong & 91 & 45.50 \\
Employee performance & Poor & 86 & 43.00 \\
& Good & 114 & 57.00 \\
\hline
\end{tabular}

\section{The result of bivariate analysis}

The bivariate analysis aimed to explain the relationship between one independent variable (job satisfaction and organizational commitment) and one dependent variable (employee performance). The results of the bivariate analysis can be seen in Table 4 .
There was an effect of job satisfaction on the performance of the PKB employees. Employees with high job satisfaction (72.09\%) had better performance than those with low job satisfaction. Employees with high job satisfaction were 8.84 times more likely to perform better than low job satisfaction. 
There was an effect of organizational commitment on the performance of PKB employees. Employees with strong organizational commitment (71.43\%) had better performance than those with weak organizatio- nal commitment. Employees with strong organizational commitment were 4.84 times more likely to perform better than weak organizational commitment.

Table 4. Bivariate analysis

\begin{tabular}{|c|c|c|c|c|c|c|c|c|}
\hline \multirow{3}{*}{ Variable } & \multicolumn{4}{|c|}{ Employee performance } & \multirow{2}{*}{\multicolumn{2}{|c|}{ Total }} & \multirow{3}{*}{$\mathbf{O R}$} & \multirow{3}{*}{$\mathbf{p}$} \\
\hline & \multicolumn{3}{|c|}{ Poor } & \multirow{2}{*}{$\begin{array}{c}\text { Good } \\
\%\end{array}$} & & & & \\
\hline & $\mathbf{N}$ & $\%$ & $\mathbf{N}$ & & $\mathbf{N}$ & $\%$ & & \\
\hline \multicolumn{9}{|l|}{ Job satisfaction } \\
\hline High & 50 & 70.42 & 21 & 29.58 & 71 & 100.00 & 8.84 & $<0.001$ \\
\hline Low & 36 & 37.91 & 93 & 72.09 & 129 & 100.00 & & \\
\hline \multicolumn{9}{|l|}{$\begin{array}{l}\text { Organizational } \\
\text { commitment }\end{array}$} \\
\hline Weak & 60 & 55.05 & 49 & 44.95 & 109 & 100.00 & 4.84 & $<0.001$ \\
\hline Strong & 26 & 28.57 & 65 & 71.43 & 91 & 100.00 & & \\
\hline
\end{tabular}

Table 5. The analysis of the multiple logistic regression on several variables with employee performance

\begin{tabular}{|c|c|c|c|c|}
\hline \multirow{2}{*}{ Employee performance } & \multirow{2}{*}{$\begin{array}{l}\text { Regression } \\
\text { coefficient }\end{array}$} & \multicolumn{2}{|c|}{ CI 95\% } & \multirow{2}{*}{$\mathbf{p}$} \\
\hline & & Lower & Upper & \\
\hline \multicolumn{5}{|l|}{ Fixed Effect } \\
\hline Job satisfaction (high) & 2.36 & 1.49 & 3.22 & $<0.001$ \\
\hline Organizational commitment (strong) & 1.68 & 0.89 & 2.47 & $<0.001$ \\
\hline \multicolumn{5}{|l|}{ Random Effect } \\
\hline \multicolumn{5}{|l|}{ PKB Office } \\
\hline \multicolumn{5}{|l|}{ Log likelihood= -108.22} \\
\hline \multicolumn{5}{|l|}{ LR test vs. logistic regression $\mathrm{p}=0.142$} \\
\hline chibar2 $(01)=1.15$ & & & & \\
\hline $\mathrm{ICC}=10.75 \%$ & & & & \\
\hline
\end{tabular}

\section{The result of multilevel analysis}

Multivariate analysis used multilevel multiple logistic regression methods and analyzed using Stata 13. Table 5 shows that PKB employee performance was affected by job satisfaction and organizational commitment. PKB employee performance increased with poor good job satisfaction $(\mathrm{b}=2.36$; $95 \% \mathrm{CI}=1.49$ to 3.22; p <0.001) and good organizational commitment $(\mathrm{b}=1.68 ; 95 \% \mathrm{CI}=0.89$ to 2.47 ; $\mathrm{p}<0.001)$. PKB office had a contextual effect on employee performance with ICC $=10.75 \%$.

\section{DISCUSSION}

1. The Effect of Job Satisfaction on Employee Performance

The results of this study indicated that there was a positive effect of job satisfaction $(b=-$ $2.36 ; 95 \% \mathrm{CI}=1.49$ to $3.22 ; \mathrm{p}<0.001$ ) on employee performance. The employees with high job satisfaction had 2.36 units higher logodd of performing well than those with low job satisfaction.

According to Soegihartono (2012), employees who were satisfied with their work would have a positive effect on individual performance achievement. This finding is in 
line with the results of a previous study that work had a positive effect on employee performance (Cahyandaru et al., 2019; Nur, 2013).

Employees with a high level of job satisfaction had positive feelings about the job, while the dissatisfied employees had negative feelings about their work (Sunuharjo and Ruhana, 2016). When productivity and satisfaction data were overall collected for the organization, the organization that had more satisfied employees tended to be more effective than the organization that had dissatisfied employees. This is in line with the statement that employees who were satisfied with their work tended to perform better. Therefore, the effect of job satisfaction on employee performance could be accepted (Renyut et al., 2017).

Osiokalu et al. (2015) investigated the relationship between job satisfaction and performance. Based on the result of the study, there was a positive and significant correlation between job satisfaction and performance. Hutabarat (2015) found in their study that job satisfaction had a positive and significant effect on job performance. The results of further study aim to determine the relationship between the two variables, namely job satisfaction and performance, where both of them showed significant and positive results on middle-level leaders. The result is in line with previous studies which strengthen the concept of the relationship between the two variables (Al -Ajouni, 2015).

\section{The Effect of Organizational Com- mitment on Employee Performance} The result of this study indicated that there was a positive effect of organizational commitment $(b=1.41 ; 95 \% \mathrm{CI}=0.39$ to $2.42 ; \mathrm{p}=-$ o.007) on employee performance. Employees with a strong organizational commitment had 1.41 units higher logodd of performing well than those with a weak organizational commitment.
Organizational commitment was an attitude that reflected employee loyalty to the organization. Attitude was a general evaluation made by humans, other people, objects, or problems which were certain regularities in terms of feelings, thoughts, and actions (Kurniavie et al,, 2020). An individual's commitment to the profession and organization where she/he worked was a very important issue. Empirically, Kertabudi and Aripin (2015) explained the effect of organizational commitment and job satisfaction on job performance. It showed that increasing job satisfaction in the organization was greatly important.

Several organizations dared to include a commitment as an element as one of the requirements for holding a position offered in job vacancies. It showed the importance of commitment in the world of the carrier. Commitment to work in a company was inseparable from the form of a relationship between the employee and the job or profession where the employee worked to achieve the business goals desired by the company (Eliyana et al., 2019).

Organizational commitment mediated the effect of satisfaction on working conditions, salary, supervision, and security on both affective and behavioral tendencies toward change. In addition, continuance commitment (the low perceived alternative) mediated the effect of satisfaction with the fees on cognitive attitudes toward change. The results showed that cognitive attitude on change increase with increased satisfaction with salaries, while affective attitude towards change increased with increasing satisfaction with promotion (Yousef, 2016).

\section{PKB office on employee perfor- mance}

The contextual of PKB office had an IntraClass Correlation (ICC) result by $10.75 \%$. This value was an indicator that the PKB office had a contextual effect on employee perfor- 
mance variations. The results of the ICC were greater than the rule of thumb of multilevel analysis. Therefore, the strata that described the PKB offices needed attention.

This result is in line with a study conducted by Gilmore et al. (2016) that one of the factors that contribute to the health workers performance was the contextual effect of the environment that allowed employees to perform their duties effectively. The differences in each PKB office in this study were caused by various factors, including work culture, work stress, work facilities, and so on.

\section{AUTHOR CONTRIBUTION}

Ikhtiarisca Olifia Mufidatun as the main researcher who played a role in coordinating the study, conducting all stages of the study, and completing the study paper. Didik Gunawan Tamtomo played a role in developing the study ideas, design, and hypotheses. Bhisma Murti played a role in compiling the theoretical framework, processing the data, representing the results of the analysis, and preparing the papers.

\section{CONFLICT OF INTEREST}

The authors declare that there is no conflict of interest in the publication of this article.

\section{FUNDING AND SPONSORSHIP}

This study used personal funds from the main researcher.

\section{ACKNOWLEDGEMENT}

The researchers would like to thank the PKB of the D.I. Yogyakarta Province who allowed to carry out this study. The researchers also would like to thank to all PKB employees who have been willing and cooperative to become the respondents of this study.

\section{REFERENCE}

Al-Ajouni (2015). Job satisfaction and performance in Jordania Banks. Int J Hum
Soc Sci, 5(11), 110-119

Bangun W (2012). Manajemen sumber daya manusia. Jakarta: Erlangga

Cahyandaru Z, Tamtomo D, Soemanto RB (2019). Linear Regression Analysis on Factors Affecting Health Surveillance Personnel Performance in Early Detection of Preeclampsia in Semarang, Central Java. J Health Policy Manage, 4(1), 13-22. https://doi.org/10.26911/thejhpm.2019.04.0

Eliyana A, Ma'arif S, Muzakki (2019). Job satisfaction and organizational commitment effect in the transformational leadership towards employee performance. Eur Res Manag Bus Econ, 25(3), 144-150. https://doi.org/10.1016/j.iedeen.2019.05.001

Gilmore B, Adams BJ, Bartoloni A, Alhaydar B, McAuliffe E, Raven J, Vallières F (2016). Improving the performance of community health workers in humanitarian emergencies: a realist evaluation protocol for the PIECES programme. BMJ Open, 6(8), eo11753. https://doi.org/10.1136/BMJOPEN-2016-011753

Hutabarat (2015). Investigation of teacher job-performance model: Organizational culture, work motivation, and job satisfaction. Asian Soc Sci, 11(18), 295-304

Kertabudi I, Aripin (2015). Effect organizational commitment and job satis-faction on employees performance at Cibabat Hospital, Cimahi City West Java. Aust J Basic Appl Sci, 9(33): 346351.

Kurniavie LE, Pawito, Murti B. (2020). The Association Between the Integrated Health Post Activity and the Performance of Community Health Workers in Child Growth and Development Care Service in Karanganyar, Central Java. J Health Policy Managt, 5(1), 48-6o. https://doi.org/10.26911/thejhpm.2020.- 
05.01.05

Nur S (2013). Konflik, Stres Kerja dan Kepuasan Kerja Pengaruhnya terhadap Kinerja Pegawai Pada Universitas Khairun Ternate. Jurnal EMBA, 1(3), 739-749

Osiokalu O, Pngunleye A, Effiong J (2015). Organizational trust, job satisfac-tion, and job performance among teacher in Ekiti State, Nigeria. British Open Journal of Humanities and Social Science Invention, 4(9), 41-49

Renyut BC, Modding HB, BimaJ, Sukmawati $S$ (2017). The effect of organizational commitment, competence on Job satisfaction and employees performance in Maluku Governor's Office. 19(11), 1829. https://doi.org/10.9790/487X-1911031829

Siagian SP (2003). Teori dan praktek kepe- mimpinan. Jakarta: Rineka Cipta Soegihartono A (2012). Pengaruh Kepemimpinan dan Kepuasan Kerja Terhadap Kinerja dengan Mediasi Komitmen (di PT Alam Kayu Sakti Semarang). Jurnal Mitra Ekonomi Dan Manajemen Bisnis, 3(1), 123-140

Sunuharjo BS, Ruhana I (2016). Studi pada PT. Telekomunikasi Indonesia, Tbk Witel Jatim Selatan, Malang. Jurnal Administrasi Bisnis (JAB), 34(1): 38-46. Retrieved from administrasibisnis.studentjournal.ub.ac.id

Yousef DA (2016). Organizational commitment, job satisfaction and attitudes toward organizational change: A study in the local government. 0692(March). https://doi.org/10.1080/01900692.2015.1072217. 